\title{
PENGEMBANGAN ANTIVIRUS BERBASIS CLIENT SERVER
}

\author{
Richki Hardi \\ Program Studi Teknik Informatika \\ Sekolah Tinggi Teknologi (STITEK) Bontang \\ J. Ir. H. Juanda No 73 RT 36 Bontang Selatan \\ Email : richkihardi@stitek.ac.id
}

\begin{abstract}
The era of globalization is included era where the komputer virus has been growing rapidly, not only of mere academic research but has become a common problem for komputer users in the world. The effect of this loss is increasingly becoming the widespread use of the Internet as a global communication line between komputer users around the world, based on the results of the survey CSI / FB. Along with the progress, komputer viruses undergo some evolution in shape, characteristics and distribution medium such as Worms, Spyware Trojan horse and program Malcodelain. Through the development of server-based antivirus clien then the user can easily determine the behavior of viruses and worms, knowing what part of an operating system that is being attacked by viruses and worms, making itself a development of network-based antivirus client server and can also be relied upon as an engine fast and reliable scanner to recognize the virus and saving in memory management.
\end{abstract}

Keywords: anti-virus, clien server, network, internet, operating systems

\section{Abstrak}

Era globalisasi adalah termasuk era dimana virus komputer telah berkembang pesat, tidak hanya dari sekedar riset akademis melainkan sudah menjadi masalah umum bagi para pengguna komputer di dunia. Efek kerugian ini semakin menjadi dengan maraknya penggunaan internet sebagai jalur komunikasi global antara pengguna komputer di seluruh dunia, berdasarkan hasil survei CSI/FB. Seiring dengan perkembangannya, virus komputer mengalami beberapa evolusi dalam bentuk, karakteristik serta media penyebarannya seperti Worms, Spyware, Trojan horse dan program Malcodelain. Melalui Pengembangan antivirus berbasis clien server maka user dapat dengan mudah mengetahui tingkah laku dari virus dan worm, mengetahui bagian apa saja dari sebuah sistem operasi yang diserang oleh virus dan worm, membuat sebuah pengembangan antivirus sendiri berbasis jaringan client server serta dapat juga diandalkan sebagai sebuah engine scanner yang cepat dan handal untuk mengenali virus dan hemat dalam manajemen memori.

Kata kunci: antivirus, clien server, jaringan, internet, sistem operasi

\section{PENDAHULUAN}

Perkembangan ilmu pengetahuan dan teknologi kian pesat, hal tersebut dapat dilihat dan dirasakan secara langsung maupun tidak langsung. Perkembangan tersebut tengah berdampak pada segala aspek kehidupan manusia. Globalisasi yang terjadi sekarang ini mengakibatkan terjadinya perubahan-perubahan yang dampaknya mempengaruhi segala aspek kehidupan dan terjadi secara berkelanjutan, termasuk permasalahan komputer dalam menangani virus dan antivirus. Banyaknya efek yang dittimbulkan oleh virus juga bermacam-macam. Efek yang ditimbulkan ini sebagian besar bersifat negatif. Beberapa efek yang umum terjadi pada komputer yang terinfeksi virus diantaranya menghilangkan file bahkan ada yang menghabisi semua isi hardisk, membuat komputer hank, menampilkan tulisan aneh dan lainnya. Virus bereproduksi tanpa sepengetahuan pemilik komputer, secara umum virus memiliki fase reproduksi, melakukan aksi melipatgandakan diri, menyerang dan melakukan tindakan apapun untuk merusak. Sampai sekarang virus menjadi momok yang paling ditakuti dan menjadi musuh para pengguna komputer, bagi pengguna komputer awam, hal ini menjadi ancaman menakutkan atas keselamatan data dan sistem komputer. 


\section{RUMUSAN MASALAH}

Adapun permasalahan dalam penelitian ini dapat dirumuskan sebagai berikut :

1. Bagaimana mengetahui bahwa komputer sudah terinfeksi virus?

2. Sikap yang tepat untuk mengatasi virus komputer

3. Penerapan tool antivirus komputer klien dan server

\section{KEASLIAN PENELITIAN}

Penelitian sejenis yang pernah dilakukan oleh peneliti sebelumnya dilakukan dengan cara menggunakan antivirus berbayar maupun trial terhadap komputer desktop, yang mana pada penelitian sebelumnya hanya sebagai pembanding beberapa antivirus. Dasar tersebut di atas penulis akan mencoba melakukan penelitian yang bersifat mengembangkan antivirus tersebut berbasis klien server atau jaringan, sampai dengan saat ini sepanjang yang penulis ketahui, belum ada dan belum pernah dilakukan penelitian tentang pengembangan antivirus berbasis klien server.

\section{MANFAAT PENELITIAN}

Manfaat dari penelitian adalah diharapkan dapat menjadi salah satu acuan bagi para pengguna komputer stand alone maupun yang terhubung jaringan/ internet dalam pemakaian antivirus terhadap komputer yang telah terinversi virus. Diharapkan dapat memberikan sumbangan bagi pengembang ilmu di bidang komputer dan informatika serta memanfaatkan kemajuan teknologi untuk kemajuan masyarakat, pembelajaran bagi mahasiswa teknik informatika khususnya dan sebagai implementasi ilmu pengetahuan dari penelitian tersebut.

\section{TUJUAN PENELITIAN}

Tujuan penelitian ini adalah memberikan sebuah pengembangan perancangan dan implementasi antivirus komputer berbasis klien server atau jaringan.

\section{BATASAN MASALAH}

Berdasarkan latar belakang masalah tersebut, agar hasil penelitian ini maksimal maka pembahasan masalah hanya dibatasi pada:

1. Penggunaan antivirus yang tepat bagi komputer yang terinfeksi virus

2. Penerapan antivirus berbasis klien server

3. Pemulihan pasca serangan virus

\section{METODOLOGI}

1) Lokasi Penelitian Lokasi penelitian di laboratorium komputer Sekolah Tinggi Teknologi (STITEK) Bontang

2) Alat dan Bahan Penelitian

Alat penelitian berupa

\section{Perangkat Keras}

Perangkat keras yang digunakan dalam penelitian ini yaitu : Spesifikasi perangkat keras (hardware) yang digunakan pada penelitian ini berupa Laptop dengan spesifikasi tinggi Intel Core2Duo, Memory 2GB, dan nVidia Graphic 512MB, Serta peralatan jaringan komputer kabel utp, switch, perangkat wireless dan lain-lain untuk memudahkan peneliti dalam melakukan penelitian.

\section{Perangkat Lunak}

Perangkat lunak yang digunakan dalam penelitian ini yaitu: Microsof Windows 7 untuk mengoperasikan program-program aplikasi dalam melaksanakan penelitian ini. Program virus dan Antivirus.

3) Bahan Penelitian

Bahan penelitian yang dibutuhkan adalah data atau file virus, aplikasi antivirus, dan media sharing jaringan komputer.

4) Metode Pengumpulan Data

Metodologi yang digunakan adalah analisis dan desain terstruktur dengan tahap-tahap sebagai berikut:

1) Penelitian Lapangan (Field Research)

Dalam melakukan penelitian ini penulis melakukan Observasi, diskusi forum, implementasi pengembangan sistem serta melakukan uji coba

2) Penelitian Kepustakaan (Library Research) 
Metode ini merupakan metode pengumpulan data dengan cara mempelajari literature, paket modul dan panduan, buku-buku pedoman, buku-buku perpustakaan dan segala kepustakaan lainnya yang dianggap perlu dan mendukung.

5) Langkah-langkah Penelitian

Ada tiga tahapan penelitian diantaranya tahapan perancangan pengembangan, menjalan aplikasi dan pengujian aplikasi berbasis klien server.

\section{HASIL DAN PEMBAHASAN}

Untuk menangani penyakit adalah dengan memberikan antibiotik atau vaksin. Begitu juga dengan penanganan virus komputer adalah dengan menggunakan antivirus. Antivirus komputer bertujuan untuk memeriksa dan menghapus virus. Virus awalnya bersifat pasif, berupa file atau aplikasi, akan aktif apabila user menjalankan virus tersebut, kemudian membuat induk di dalam sistem komputer dan melakukan manipulasi yang dapat menyerang atau bertahan pada sistem komputer. Berikut tahapan perjalanan virus yang diilustrasikan pada Gambar 1.

Program antivirus mampu mendeteksi virus dan mencegah akses ke dokumen yang terinfeksi dan juga mampu menghilangkan infeksi yang terjadi. Program pemindai virus merupakan jenis yang paling populer dalam dunia antivirus, tetapi program-program seperti ini harus sering diperbarui agar mampu mengenali virus-virus baru. Secara umum ada dua jenis program antivirus, yaitu on-access dan on-demand scanner.

On-access scanner akan selalu aktif dalam sistem komputer selama aktif menggunakannya. Pemindai jenis ini akan secara otomatis memeriksa dokumen-dokumen yang diakses dan dapat mencegah penggunaan akan dokumen yang sudah terinfeksi oleh virus komputer.

On-demand scanner membiarkan memulai aktivitas pemindaian terhadap semua dokumen di komputer. Hal tersebut bisa diatur agar bisa dilakukan secara periodik dengan menggunakan penjadwal.

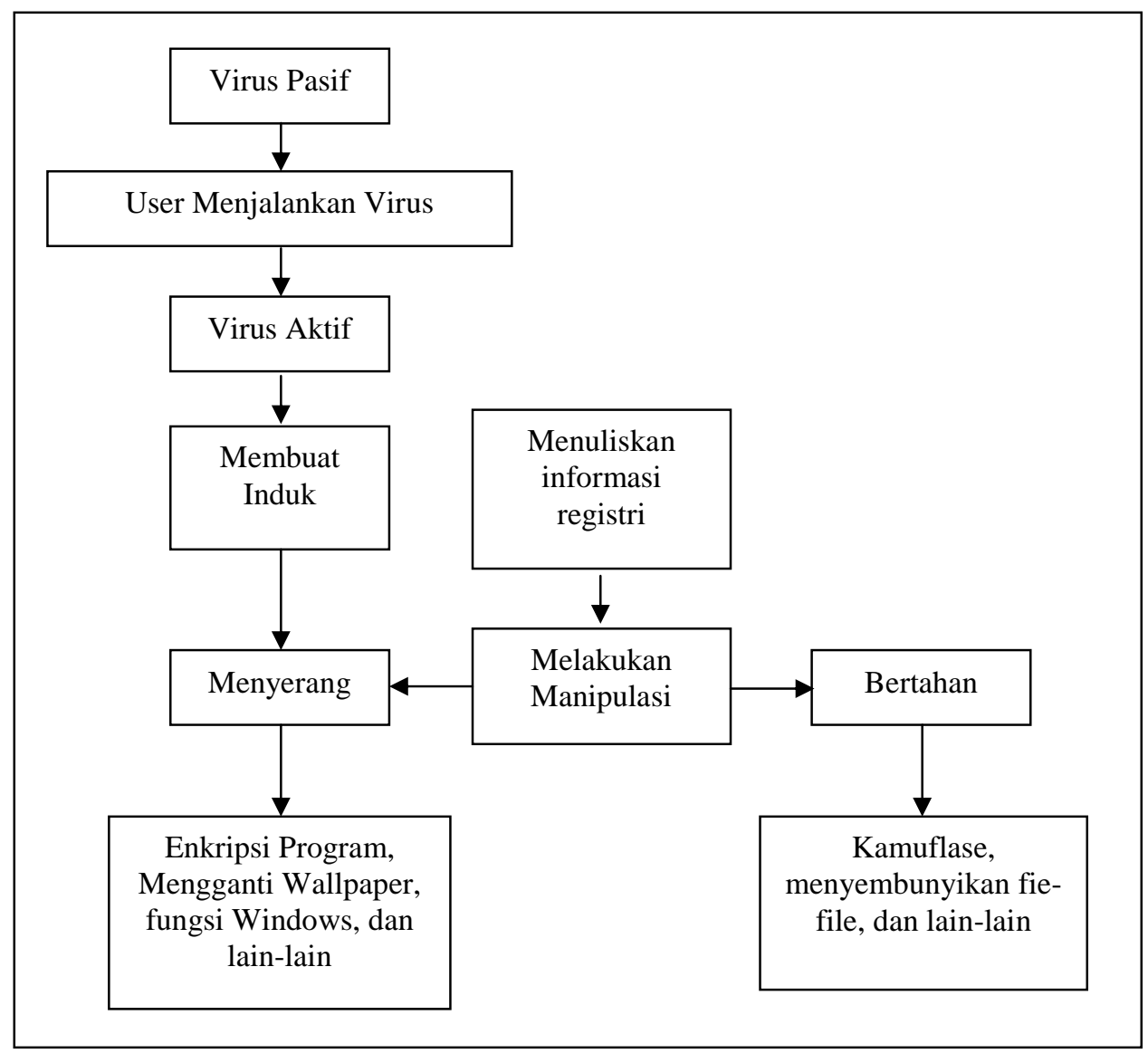

Gambar 1. Perjalanan Virus 
Ada juga jenis anti-virus yang menerapkan pemindaian secara heuristic. Cara ini memungkinkan pemindai mendeteksi virus, baik yang sudah diketahui atau belum, dengan menggunakan aturan-aturan yang umum yang menjadi indikator adanya suatu virus. Ini sangat berguna untuk mendeteksi virus-virus jenis baru atau yang belum terdeteksi sebelumnya. Jenis heuristic scanner ini tidak perlu sering diupdate tetapi efek sampingnya terkadang bisa menimbulkan kesalahan deteksi, dimana seharusnya itu dokumen atau program normal, tetapi dideteksi dan dianggap sebagai suatu virus. Berikut ini tahapan penanganan virus sebagaimana pada Gambar 2.

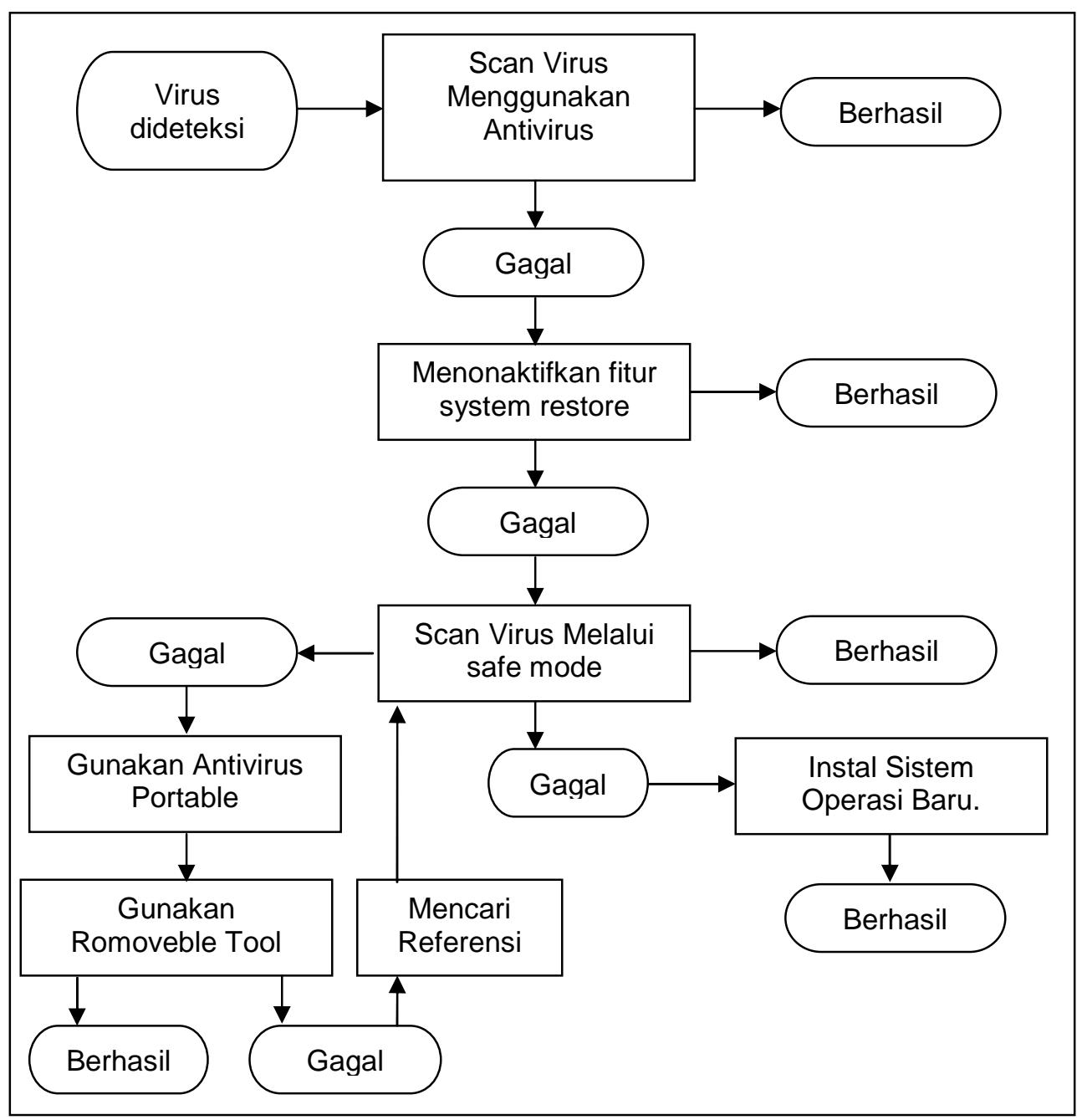

Gambar 2. Penanganan Virus

Dalam mengatasi virus, terlebih dahulu virus dideteksi oleh antivirus (scaning), bila berhasil virus tersebut dihilangkan. bila gagal maka langkah selanjutnya menonaktifkan sistem restore, bila gagal maka scan virus melalui safe mode, gunakan antivirus portable, gunakan removal tool, bila gagal mencari referensi kemudian scan virus kembali bila tetap gagal maka instal ulang sistem operasi. Pada proses klien server secara umum tergambar pada arsitektur sistem komputer seperti berikut, dimana semua komputer dapat terhubung untuk menjalankan tugas masing-masing dengan tujuan yang sama. Pada proses tersebut komputer klien maupun server dapat berbagi (sharing) data, scanner dan perangkat lainnya, sebagaimana pada arsitertur system komputer pada Gambar 3. 


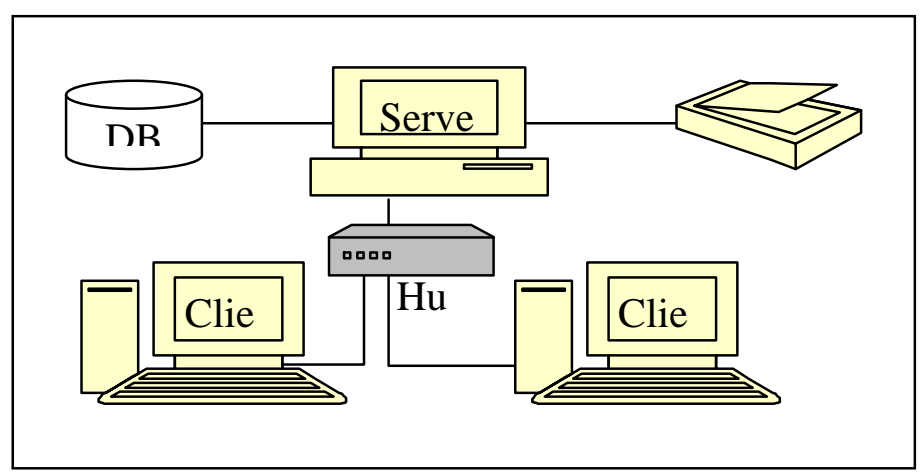

Gambar 3. Arsitektur Sistem Komputer

Sebelum melakukan proses scaning oleh antivirus, maka dilakukan pengaturan Internet Protocol (IP) terlebih dahulu, kemudian membuat workgroup yang telah tersedia pada default sistem operasi. Berikut pengaturan IP jaringan pada gambar 4.

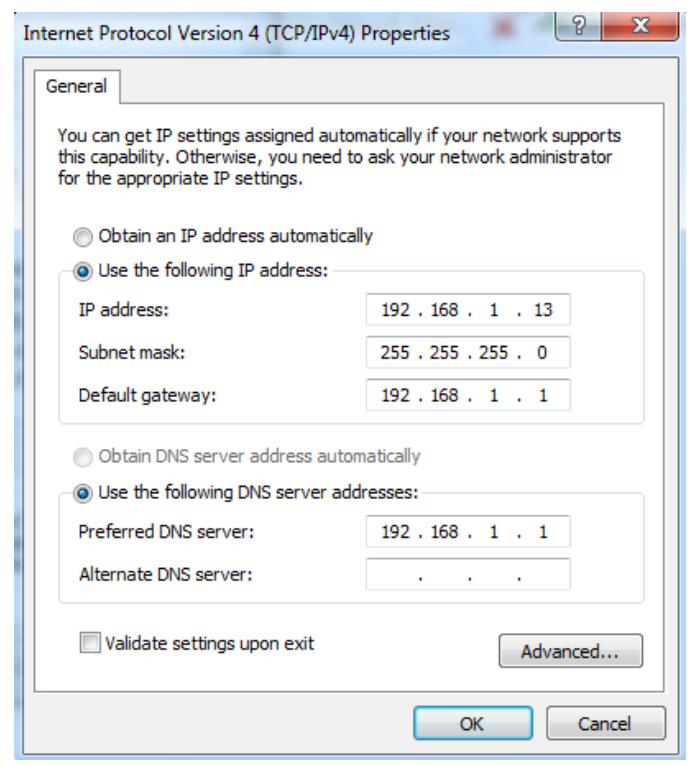

Gambar 4. Pengaturan IP Jaringan

Setelah melakukan pengaturan IP Jaringan, maka proses selanjutnya adalah menentukan pilihan scanning yang telah tersedia yang akan dikontrol atau dipilih oleh komputer/ PC Server untuk menyelesaikan masalah virus yang ada di komputer/ PC Client, sebagaimana yang ditampilkan pada Gambar 5 dan 6 .

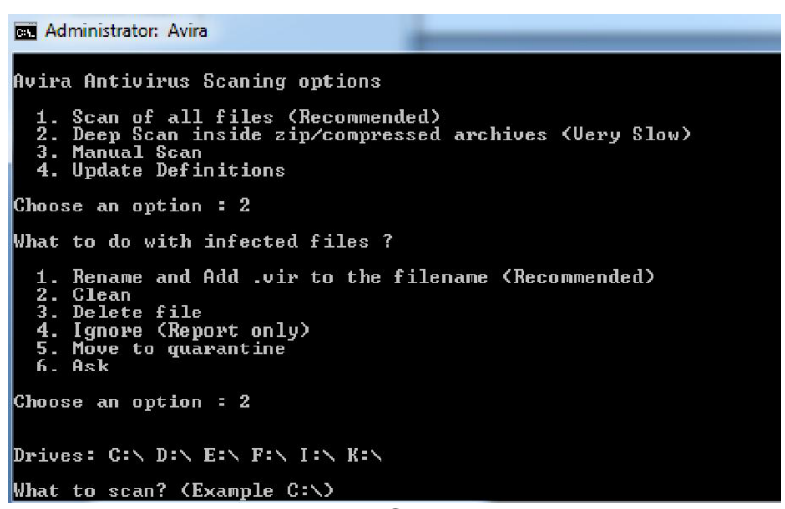

Gambar 5. Pilihan I scanning pada PC klien yang dilakukan oleh PC server 


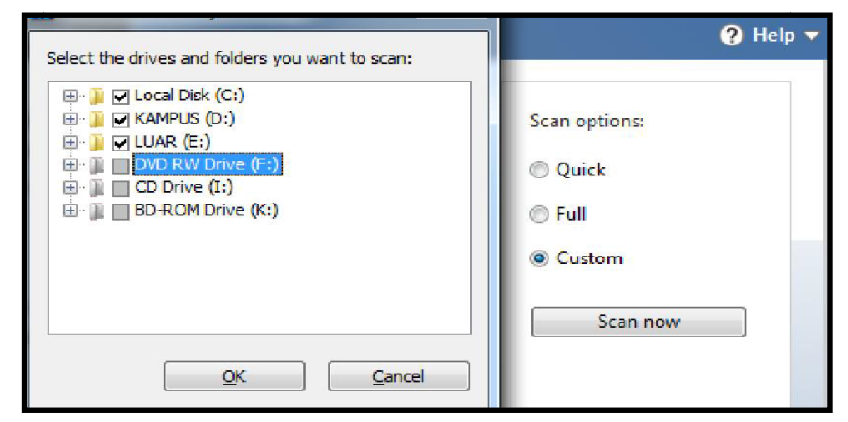

Gambar 6. Pilihan II scanning pada PC klien yang dilakukan oleh PC server

\section{Pemulihan pasca serangan virus}

Pada saat komputer telah terserang atau terinfeksi virus maka kinerja atau performa komputer masih mengalami gangguan atau tidak berjalan dengan normal walaupun telah dieksekusi oleh antivirus, maka sebaiknya perlu pemulihan dengan melakukan repair sistem operasi dan melakukan perawatan secara berkala baik dengan menggunakan tools default Sistem Operasi maupun tools lainnya seperti Tune Up Utilities, Turbo Mode, Recuva untuk mengembalikan data yang hilang dan lain-lain. Mematikan fitur Autoplay/ Autorun secara default, untuk fitur autoplay dan autorun dapat dilihat pada Gambar 7 :

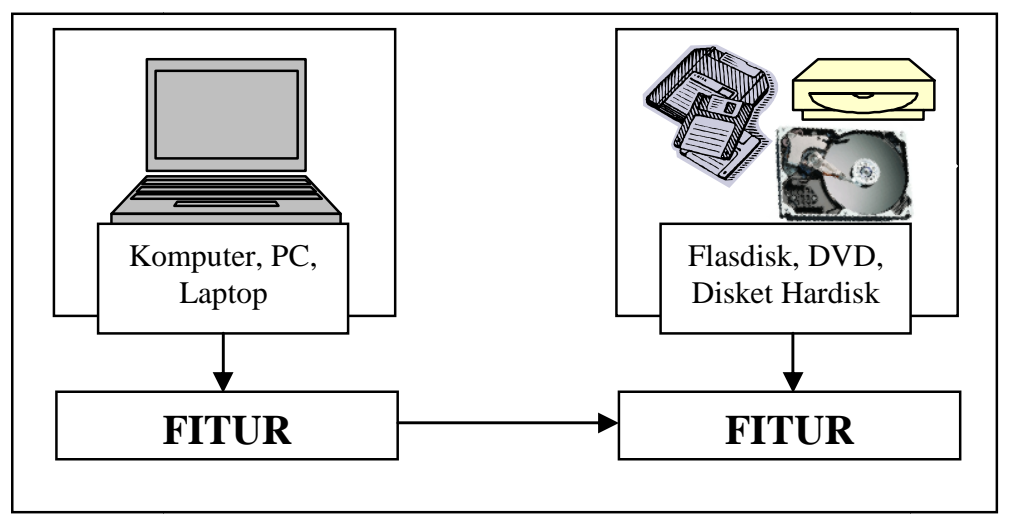

Gambar 7. Fitur Autoplay.inf dan Autorun.inf

\section{KESIMPULAN}

Proses pemakaian antivirus tersebut masih terbilang sederhana maksudnya adalah dalam proses tersebut server memilih drive atau folder mana yang perlu diperiksa atau dihapus virusnya pada computer klien. Harapan untuk menjadi saran agar dapat ditingkatkan menjadi antivirus yang otomatis mendeteksi jenis virus dan menghapusnya lewat jaringan tanpa harus memilih secara manual.

\section{DAFTAR PUSTAKA}

Aat, S., 2006, Rahasia Membuat Antivirus Menggunakan Visual Basic., DSI Publishing, Yogyakarta.

Dony, A., 2007, Interusion Detection System., Penerbit Andi, Yogyakarta

Efvy, Z.Z., 2008, Menembus Keamanan Komputer., Penerbit Gava Media, Yogyakarta .

Hirin.,A.M., Anhar 2009, Cara Mudah Membuat dan Membasmi Virus Komputer., Penerbit Mediakita, Jakarta Selatan.

Karsmakers, Richard (January 2010). "The ultimate Virus Killer UVK 2000". http://www.42nd.net/uvk/. Retrieved 22 August 2011.

Ketut, D., 2007, Program Aplikasi Client Server., Penerbit Informatika, Bandung.
Landesman,
Mary
(2009).
"What
is
Virus
Signature?". http://antivirus.about.com/od/whatisavirus/a/virussignature.htm. Retrieved 2009-06-18. 
Madcoms., Andi., P., 2011, Langkah Cerdas Membasmi Virus Komputer., Penerbit Andi \& Madcoms., Yogyakarta.

Michael Kaiser (April 17, 2009). "Small and Medium Size Businesses are Vulnerable". National Cyber Security Alliance. http://www.staysafeonline.org/blog/small-and-medium-sizebusinesses-are-vulnerable. Retrieved 2011-02-24.

Robert Vamosi (May 28, 2009). "G-Data Internet Security 2010". PC World. http://www.pcworld.com/article/165600/gdata_internet_security_2010.html. Retrieved 2011-02-24.

Tri, A., 2008, Membuat dan Membasmi Worm - Virus., Penerbit Elex Media Komputindo, Jakarta.

Wahana, K., Andi, P., 2012, Mengenal virus dan cara penanggulangannya, Wahana Komputer \& Penerbit Andi, Yogyakarta.

Wells, Joe (1996-08-30). "Virus timeline". IBM. Archived from the original on 4 June 2008. http://www.research.ibm.com/antivirus/timeline.htm. Retrieved 2008-06-06.

Zeltser, Lenny (October 2010). "What Is Cloud Anti-Virus and How Does It Work?". Archived from the original on 10 October 2010. http://blog.zeltser.com/post/1256199682/what-iscloud-anti-virus. Retrieved 2010-10-26. 